\title{
New species of Moenkhausia Eigenmann (Ostariophysi: Characidae) from the upper rio Tocantins basin in Central Brazil
}

\author{
Vinicius A. Bertaco ${ }^{1}$, Fernando C. Jerep ${ }^{2}$ and Fernando R. Carvalho ${ }^{1}$
}

Moenkhausia dasalmas is described from the upper rio Tocantins basin, in the Chapada dos Veadeiros region, Goiás State, Central Brazil. The new species differs from all congeners by the presence of iii,9 rays in the dorsal fin. It can also be distinguished from its congeners by the presence of two humeral spots (first one vertically elongate and second one faint), by the number of branched anal-fin rays (17-19), lateral line scales (36-37), maxillary teeth (4-5), and a vertical dark spot in the caudal peduncle end.

Moenkhausia dasalmas é descrita da bacia do alto rio Tocantins, Chapada dos Veadeiros, Goiás, Brasil Central. A espécie nova difere de todas as suas congêneres pela presença de iii,9 raios na nadadeira dorsal. Ela também se distingue das suas congêneres por apresentar duas manchas umerais (a primeira verticalmente alongada e a segunda tênue), 17-19 raios ramificados na nadadeira anal, 36-37 escamas na linha lateral, quatro a cinco dentes no maxilar e uma mancha vertical e escura no final do pedúnculo caudal.

Key words: Brazilian Cerrado, Chapada dos Veadeiros, Characiformes, Tocantins-Araguaia basin.

\section{Introduction}

The genus Moenkhausia Eigenmann is a speciose group of characid fishes comprising 71 valid species widespreadly distributed in the Neotropical Cis-Andean river basins, except for those in Patagonia (Lima et al., 2003; Eschmeyer \& Fricke, 2010; Marinho, 2010). None of the diagnostic characters presently used to recognize Moenkhausia is unique to the genus, e.g. premaxillary teeth in two rows, five or more teeth on the inner premaxillary row, complete lateral line, and caudal fin scaled, but shared with other incertae sedis Characidae such as Astyanax Baird \& Girard, Hemigrammus Gill, and Hyphessobrycon Durbin.

Eigenmann (1917) is still the most complete reference to the taxonomy of Moenkhausia, and Géry (1977) made the last survey on the genus presenting a comparative key and brief diagnosis to the species. Those authors recognized species groups based mainly on similarities of body depth, scale counts and color pattern. No hypothesis of intrageneric relationships of Moenkhausia species is available at the moment, and the genus is probably non-monophyletic according to Mirande (2010), whose weighted parsimony phylogenetic analysis of Characidae presented Moenkhausia as a paraphyletic genus with Bario Myers, inside of a new redefined Tetragonopterinae.

The new species was collected in rivers and streams of the upper rio Tocantins basin, in the Chapada dos Veadeiros region, during a recent expedition, and is herein described.

\section{Material and Methods}

Counts were taken as described by Fink \& Weitzman (1974), with the exception of the number of scale rows below the lateral line, which were counted from the scale row ventral to lateral line to the scale row nearest the first pelvic-fin ray. Counts of vertebrae, supraneurals, gill rakers on the first arch, branchiostegal rays, procurrent caudal-fin rays, and small dentary teeth were taken from cleared and stained (c\&s) specimens prepared according to Taylor \& van Dyke (1985). The count of unbranched dorsal-fin rays does not include the tiny ray commonly observed only in cleared and stained specimens. Vertebral counts include the four vertebrae of the

\footnotetext{
${ }^{1}$ Universidade Federal do Rio Grande do Sul, Instituto de Biociências, Departamento de Zoologia, Laboratório de Ictiologia. Av. Bento Gonçalves, 9500, 91501-970 Porto Alegre, RS, Brazil.vbertaco@gmail.com, frcarvalho2004@yahoo.com.br

${ }^{2}$ Setor de Ictiologia, Museu de Ciências e Tecnologia, Pontifícia Universidade Católica do Rio Grande do Sul. Av. Ipiranga 6681, Cx. Postal 1491, 90619-900 Porto Alegre, RS, Brazil. fjerep@gmail.com
} 
Weberian apparatus, and the terminal centrum as a single element. Drawings of the upper and lower jaws and the infraorbital series of one $c \&$ s specimen were prepared under a stereomicroscope with camera lucida.

Measurements were made with an electronic caliper from the left side of the specimens, and presented as percents of the standard length (SL) or the head length (HL). In the description, the asterisk indicates the value presented by the holotype. In the list of paratypes and material examined, the whole number of specimens in the lot is followed by the number of those counted and measured, and cleared and stained (c\&s), in parentheses.

Specimens examined belong to the following institutions: ANSP, Academy of Natural Sciences, Philadelphia; CAS, California Academy of Sciences, San Francisco; INPA, Instituto Nacional de Pesquisas da Amazônia, Manaus; MCP, Museu de Ciências e Tecnologia, Pontifícia Universidade Católica do Rio Grande do Sul, Porto Alegre; MNRJ, Museu Nacional, Rio de Janeiro; MZUSP, Museu de Zoologia da Universidade de São Paulo, São Paulo; UFRGS, Departamento de Zoologia, Universidade Federal do Rio Grande do Sul, Porto Alegre, and USNM, National Museum of Natural History, Smithsonian Institution, Washington D.C.

\section{Moenkhausia dasalmas, new species Figs. 1-5}

Holotype. UFRGS 11221, 1, 42.9 mm SL, Brazil, Goiás, Cavalcante, tributary of the rio das Almas about $8 \mathrm{~km}$ North of Cavalcante on GO 241 road, upper rio Tocantins basin, between Cavalcante and Minaçu, 1343'13's 47²7'20"W, 8 Sep 2009, V. A. Bertaco, F. C. Jerep \& F. R. Carvalho.

Paratypes. Brazil, Goiás, Cavalcante, upper rio Tocantins basin. UFRGS 11194, 24 (10; 3 c\&s), 20.5-35.8 mm SL, MCP 45679, 10 (5), 23.0-30.5 mm SL, MZUSP 106076, 8 (2), 22.3-32.9 mm SL, córrego Grotão or Rita Maria about $4 \mathrm{~km}$ North of Cavalcante on GO 241 road, between Cavalcante and Minaçu, 13\%45'18"S 47²7'20"W, 6 Sep 2009, V. A. Bertaco, F. R. Carvalho \& G. L. C. Frainer. UFRGS 11589, 4 (4), 21.5-31.0 mm SL, same locality of UFRGS 11194, 25 May 2008, F. C. Jerep \& T. P. Carvalho.

Diagnosis. Moenkhausia dasalmas is distinguished from all congeners by the presence of iii, 9 rays in the dorsal-fin, Fig. 2 (vs. ii,9). Additionally, M. dasalmas can be distinguished from most congeners by the presence of two humeral spots, in which the first one is vertically elongate (except from $M$. diamantina Benine, Castro \& Santos, M. diktyota Lima \& Toledo-Piza, M. eigenmanni Géry, M. georgiae Géry, M. inrai Géry, M. levidorsa Benine, M. moisae Géry, Planquette \& Le Bail, M. naponis Böhlke, M. pankilopteryx Bertaco \& Lucinda, and $M$. surinamensis Géry) (vs. absent, or horizontally elongate or diffuse humeral spot). Moenkhausia dasalmas differs from the remaining species by the number of branched anal-fin rays (17-19vs. 20-35). It can be further distinguished from M. diktyota, M. eigenmanni, M. georgiae, M. inrai, $M$. levidorsa, M. moisae, and M. naponis by the number of the lateral line scales (36-37 vs. 41-47 in M. moisae, and 31-35 in the remaining species), and from $M$. pankilopteryx by the number of maxillary teeth (4-5 vs. 2-3) and the shape of the caudal peduncle spot (vertically elongate $v s$. horizontally elongate in M. pankilopteryx).

Description. Morphometric data summarized in Table 1. Body compressed, moderately short, greatest body depth usually located anterior to dorsal-fin origin. Dorsal profile of head convex from tip of upper jaw to vertical through anterior nostril; slightly straight or convex from that point to tip of supraoccipital spine. Dorsal profile of body slightly convex from posterior tip of supraoccipital spine to base of last dorsal-fin ray, and straight to adipose-fin origin. Ventral profile of body convex from tip of lower jaw to pelvic-fin origin, straight or slightly convex from that point to anal-fin origin, and straight and posterodorsally slanted along anal-fin base. Dorsal and ventral profile of caudal peduncle straight to slightly concave.

Mouth terminal, jaw isognathous. Maxilla extending posteroventrally to vertical through anterior half of orbit, aligned approximately at 45 degree angle relative to longitudinal axis of body. Maxilla slightly widened anteroposteriorly.

Two tooth rows in the premaxilla: outer row with three* to four tri- to pentacuspid teeth ( mode $=3, n=22$ ), central cusp longer; inner row with five teeth, gradually decreasing in length from first to fourth, last distinctly smaller, with five to seven cusps; central cusp twice as long and broad as others cusps. Maxilla with four to five* teeth ( $\operatorname{mode}=4, n=22$ ), three to five cusps, with central cusp slightly longer. Four anteriormost dentary teeth larger, with five or seven cusps, followed by one medium-sized tooth with five cusps, and five or seven teeth with one to three cusps. Central cusp in all teeth two to three times as long and broad as other cusps. All cusp tips slightly curved posteriorly towards inside mouth (Fig. 3).

Dorsal-fin rays iii, $9^{*}(\mathrm{n}=22)$; first unbranched ray approximately one-fifth to one-seventh of second unbranched ray, which is approximately half-length of third unbranched ray. First branched rays longest. Distal margin of dorsal fin nearly straight to somewhat convex. Adipose fin origin approximately at vertical through last anal-fin ray insertion. Anal-fin rays iv-v,17-19 (iv,18*, mode $=i v, 18, n=22)$. First unbranched ray usually apparent only in c\&s specimens. Distal profile of anal fin distal profile smoothly concave in the specimens smaller than $34.0 \mathrm{~mm} \mathrm{SL}$, and concave in the specimens larger than $34.9 \mathrm{~mm} \mathrm{SL}$. Anal fin origin posterior to vertical through base of last dorsal-fin ray. Pectoral-fin rays i, 12-13* (mode $=12, n=22)$. Pelvic-fin rays i,7* $(n=22)$. Pelvic-fin origin slightly anterior to vertical through dorsalfin origin. Tip of pelvic fin trespassing genital opening but not reaching anal-fin origin. Caudal fin forked, lobes similar in size, $19 *$ principal rays $(n=22)$. Dorsal and ventral procurrent caudal-fin rays 12-13 and 11-12, respectively $(\mathrm{n}=3)$.

Lateral line complete, with $36-37^{*}$ perforated scales (mode $=37, \mathrm{n}=19$ ). Scale rows between dorsal-fin origin and lateral line $7-8^{*}(\operatorname{mode}=7, \mathrm{n}=22)$; scale rows between lateral line 


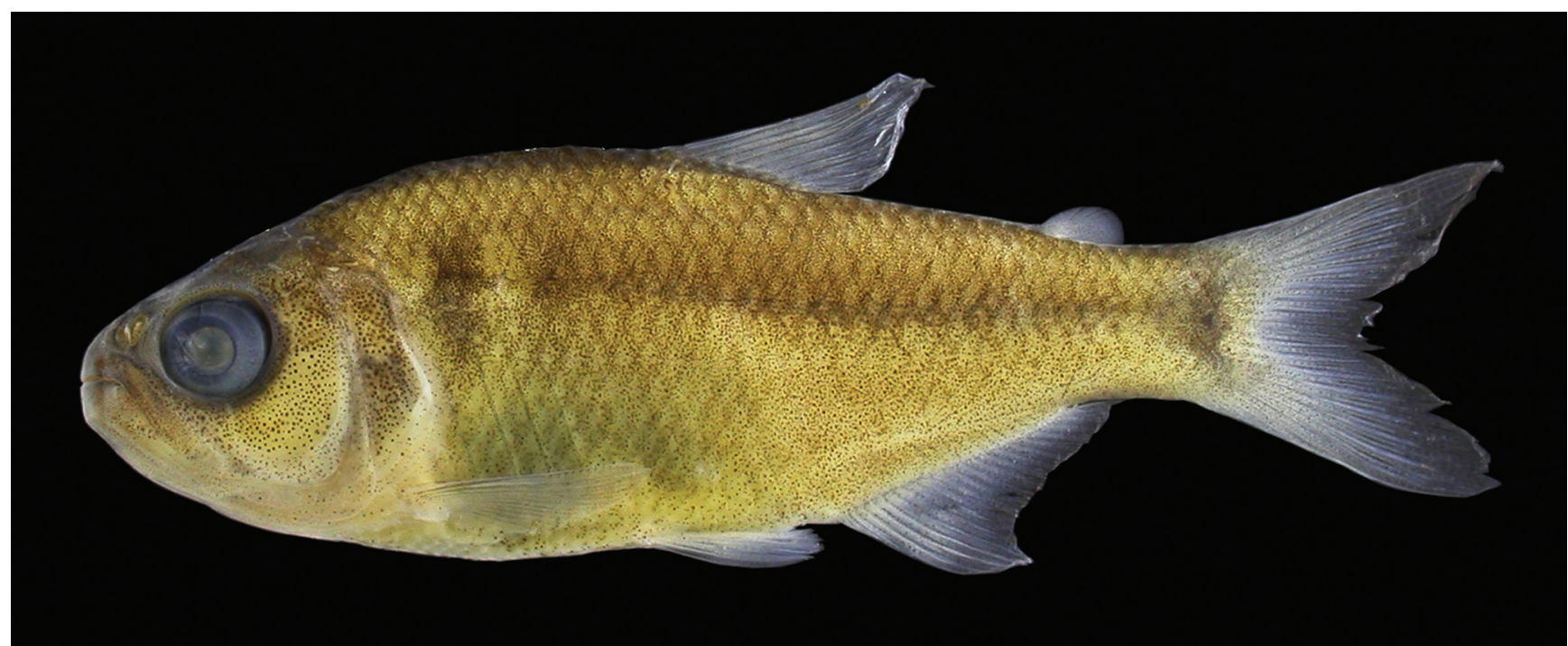

Fig. 1. Moenkhausia dasalmas, holotype, UFRGS 11221, $42.9 \mathrm{~mm}$ SL, tributary of rio das Almas, Cavalcante, Goiás, Brazil.

and pelvic-fin origin $6-7^{*}(\operatorname{mode}=7, \mathrm{n}=22)$. Predorsal scales $13-14 *($ mode $=13, \mathrm{n}=16)$ arranged in regular series. Scale rows around caudal peduncle $16-18^{*}$ (mode $=16, \mathrm{n}=16$ ). Axillary scale on pelvic fin origin covering 1-2 scales posteriorly. Scale sheath along anal-fin base 7-10 scales (9*, mode $=8, \mathrm{n}=19$ ), in single series, covering base of anteriormost rays. Caudal fin scaled, scales over base of upper and along first third of lower caudal-fin lobes; scales gradually decreasing in size posteriorly.

Infraorbitals bones $5(n=22)$, fourth and/or fifth absent or fused (Fig. 4). Precaudal vertebrae 17; caudal vertebrae 18; total vertebrae $35(\mathrm{n}=3)$. Supraneurals $5(\mathrm{n}=3)$. Branchiostegal rays $4(n=3)$. First gill arch with six rakers on epibranchial, one between epibranchial and ceratobranchial, eight in ceratobranchial, and two on hypobranchial $(\mathrm{n}=3)$.

Color in alcohol. Overall ground color of body varying from whitish to dark yellowish (Figs. 1 and 5). Dorsal portion of snout, head and body darker than remaining regions. Small melanophores scattered all over head and body, including abdominal region. Larger melanophores scattered over orbital series and opercular apparatus. Scales of longitudinal rows above lateral line series with reticulated color pattern, due to higher concentration of melanophores on their distal margin. Specimens larger than $35.0 \mathrm{~mm}$ SL also with a reticulated pattern on most anterior scales of longitudinal rows bellow lateral line series. Two vertically elongate humeral spots, separated by a less pigmented, but not completely pale area. First humeral spot conspicuous, three to four scales wide, narrowing ventrally, and vertically extending over four longitudinal scale rows above lateral line series, and three longitudinal scale rows bellow it. Second humeral spot diffuse, not as dense pigmented as first one, two to three scales wide, fainting posteriorly and ventrally, and extending vertically over four longitudinal scale rows above lateral line series, and at most one longitudinal scale row bellow it. Longitudinal stripe brownish, thinner than scales depth or absent, generally with a denser amount of scattered melanophores along its length. Longitudinal stripe, when present, extending from second humeral spot and contacting caudal peduncle spot on larger specimens, or falling short vertical through adiposefin insertion on smaller. Chevron-shaped striae (chevronshaped bars) posteriorly diverging from longitudinal line, following mioseptum lines, more evident on specimens with longitudinal line not well pigmented (Fig. 5). Caudal peduncle spot faint and vertically expanded, sometimes overlapping base of caudal-fin rays, reaching at most six longitudinal scale lines on larger specimens, but not reaching dorsal and ventral margins of caudal peduncle. All fins hyaline with some melanophores scattered along interradial membranes. Adipose fin hyaline, rarely with dispersed melanophores.

Table 1. Morphometric data for holotype and 15 paratypes of Moenkhausia dasalmas from the upper rio Tocantins basin. The range includes the holotype. SD = Standard deviation.

\begin{tabular}{lcccc}
\hline & $\mathrm{H}$ & Range & Mean & SD \\
\hline Standard length (mm) & 42.9 & $26.3-42.9$ & 31.2 & - \\
& Percents of Standard length & & & \\
Predorsal distance & 55.2 & $54.0-57.8$ & 55.5 & 1.0 \\
Prepelvic distance & 51.4 & $51.4-55.6$ & 53.4 & 1.0 \\
Prepectoral distance & 29.4 & $29.0-33.1$ & 30.7 & 1.1 \\
Preanal distance & 68.3 & $66.7-70.6$ & 68.7 & 1.0 \\
Depth at dorsal-fin origin & 36.1 & $33.4-36.9$ & 35.1 & 1.1 \\
Caudal peduncle depth & 13.4 & $11.6-13.4$ & 12.2 & 0.4 \\
Caudal peduncle length & 14.2 & $13.5-16.1$ & 14.5 & 0.7 \\
Anal-fin base & 22.4 & $21.1-24.1$ & 22.7 & 0.9 \\
Dorsal-fin length & 24.6 & $24.6-30.1$ & 27.0 & 1.5 \\
Pelvic-fin length & 15.6 & $14.4-16.9$ & 15.5 & 0.7 \\
Pectoral-fin length & 21.8 & $21.5-24.6$ & 22.0 & 0.8 \\
Head length & 30.2 & $28.9-33.0$ & 30.5 & 1.1 \\
& 20.8 & $20.8-25.3$ & 23.6 & 1.3 \\
Snout length & 48.6 & $45.3-51.6$ & 49.1 & 1.4 \\
Upper jaw length & 29.7 & $29.7-38.2$ & 35.1 & 2.0 \\
Orbital diameter & 28.6 & $25.3-28.7$ & 27.1 & 1.1 \\
Interorbital width & & & & \\
& Percents of Head length & & &
\end{tabular}




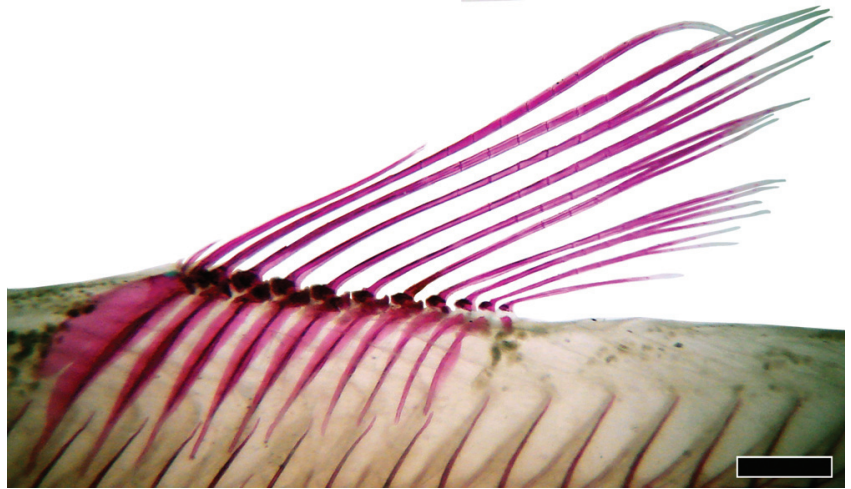

Fig. 2. Left lateral view of the dorsal fin of Moenkhausia dasalmas, paratype, UFRGS 11194, $23.3 \mathrm{~mm}$ SL, c\&s; showing the unbranched and branched rays. Scale bar $=1 \mathrm{~mm}$.

Sexual dimorphism. Secondary sexual characters were not found on examined specimens. Immature gonads were observed in one dissected and c\&s specimen (UFRGS 11194, $27.3 \mathrm{~mm} \mathrm{SL}$ ).

Distribution. Moenkhausia dasalmas is known from tributaries of the rio das Almas, rio Paranã drainage, upper rio Tocantins basin, in the Chapada dos Veadeiros region, Brazilian Cerrado, Goiás, Brazil.

Etymology. The name dasalmas is a reference to the occurrence in the rio das Almas basin, where the new species inhabit. A noun in apposition.

Ecological notes. The collection locality is around $800 \mathrm{~m}$ above sea level. Moenkhausia dasalmas inhabits streams, and occurs in semi-lentic and lotic shallow areas (up to $1.0 \mathrm{~m}$ deep) with riparian vegetation composed by trees and shrubs (Fig. 6). The streams have transparent water, and bottom with rocks, stones, and some stretches with sand. The new species was collected

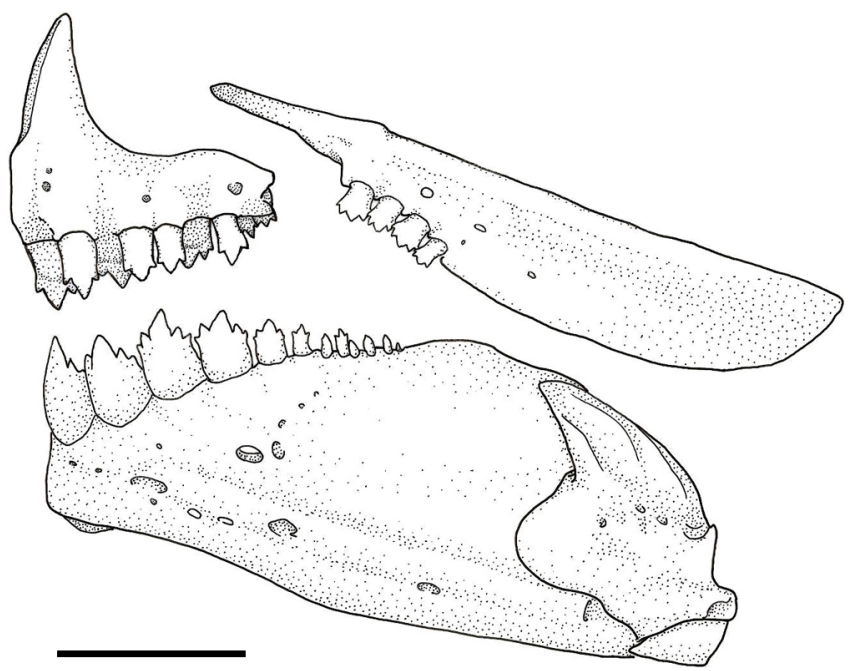

Fig. 3. Drawing of upper and lower jaws; left lateral view. Moenkhausia dasalmas, paratype, UFRGS 11194, $27.3 \mathrm{~mm}$ SL. Scale bar $=1 \mathrm{~mm}$. syntopically with Aspidoras albater Nijssen \& Isbrücker, Astyanax sp., Characidium stigmosum Melo \& Buckup, Corumbataia veadeiros Carvalho, Hemigrammus tocantinsi Carvalho, Bertaco \& Jerep, and Trichomycterus sp. Stomach contents of three specimens (UFRGS 11194, 24.4-27.3 mm SL) were mainly composed by Hymenoptera, Coleoptera (adults) and some fish scales, but autochthonous insects and digested vegetal organic matter (seeds) was also found.

\section{Discussion}

The new species, Moenkhausia dasalmas, is herein assigned to Moenkhausia according to the traditional definition of the genus given by Eigenmann $(1917,1918)$ and followed by Géry (1977), which is still in use (Bertaco \& Lucinda, 2006; Lucinda et al., 2007; Marinho, 2010; Sousa et al., 2010) due to the lack of a cladistic definition of the genus. Among the subdivisions based on body depth and number of scales above and below the lateral line that Géry (1977) assigned to the genus, Moenkhausia dasalmas is included in the M. chrysargyrea species-group, whose species possess seven or more scales above, and five or more scales below the lateral line, and a relatively deeper body. The new species differs from the representatives of that group of species, which includes $M$. chrysargyrea (Günther), M. comma Eigenmann, M. doceana (Steindachner), M. eigenmanni, M. jamesi Eigenmann, $M$. justae Eigenmann, $M$. metae Eigenmann, $M$. miangi Steindachner, M. naponis, M. pittieri, and $M$. surinamensis Géry, by the number of branched anal-fin rays (17-19vs. more than 20).

Subsequently to Géry (1977), three other species of Moenkhausia that could be assigned to the M. chrysargyrea species-group were described: M. margitae Zarske \& Géry, from the rio Ucayali drainage in Peru, M. moisae from the rio Maroni and Mana drainages in French Guiana, and $M$. pankilopteryx from rio Tocantins drainage. Moenkhausia

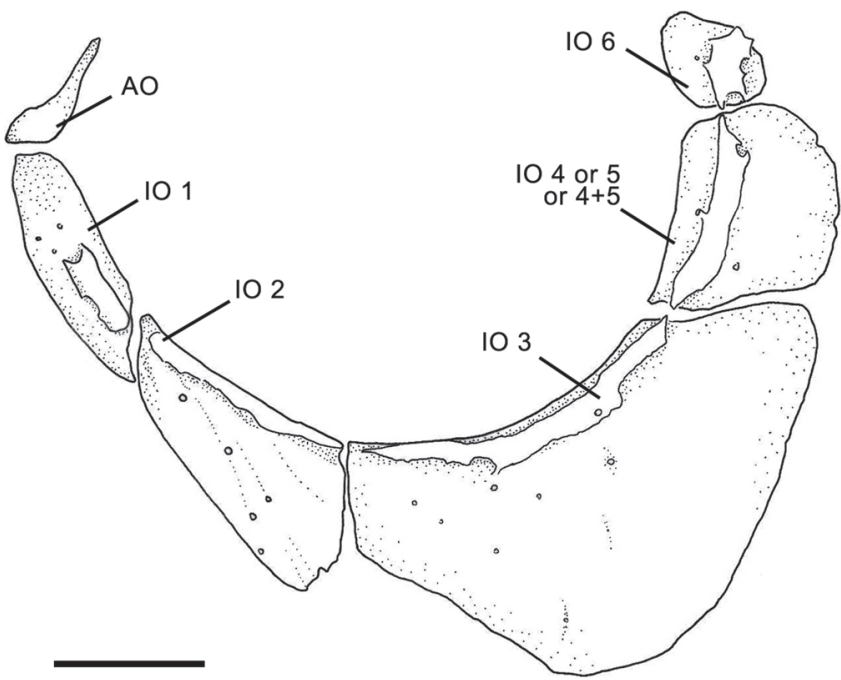

Fig. 4. Moenkhausia dasalmas, paratype, UFRGS 11194, $23.3 \mathrm{~mm}$ SL. Infraorbital series (IO1-6), and antorbital (AO); left lateral view. Scale bar $=1 \mathrm{~mm}$. 


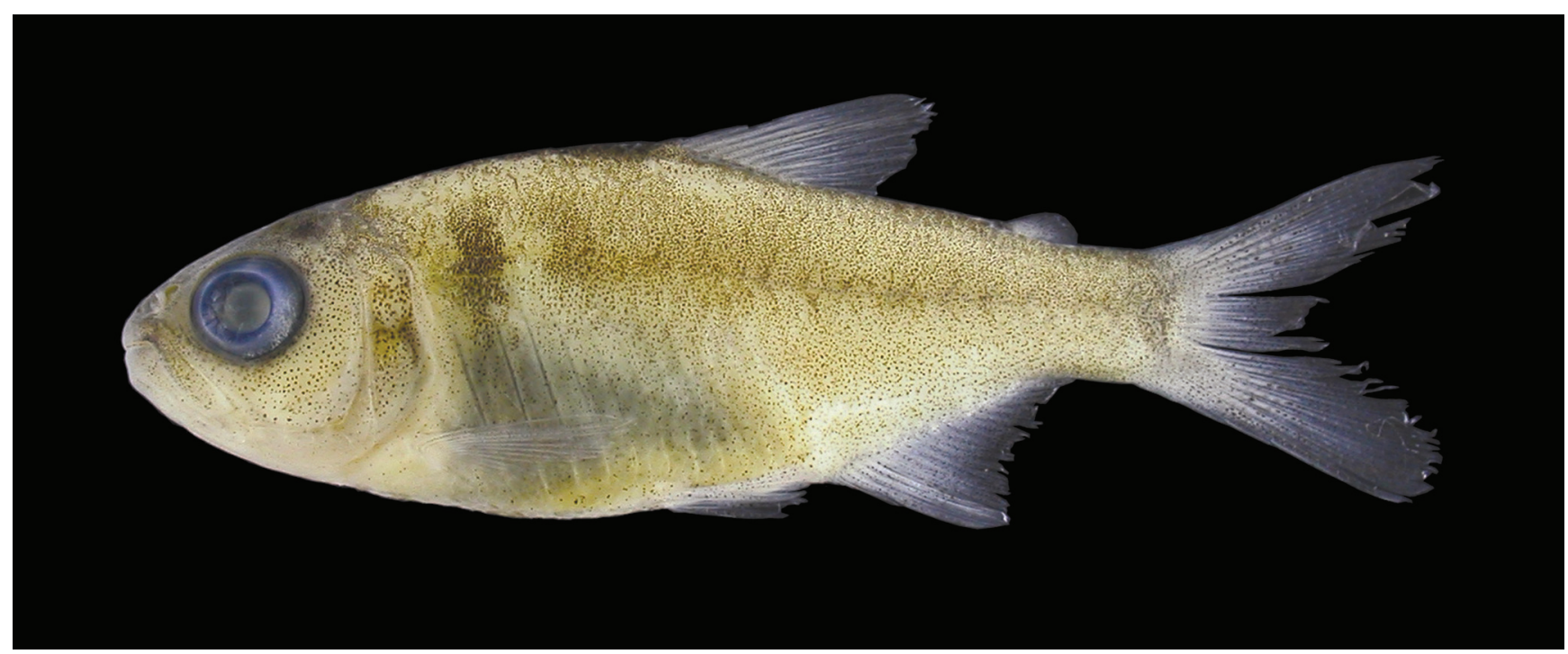

Fig. 5. Moenkhausia dasalmas, paratype, UFRGS 11194, $28.6 \mathrm{~mm} \mathrm{SL}$, tributary of rio das Almas, Cavalcante, Goiás, Brazil.

dasalmas can be distinguished from all these species by the number of branched anal-fin rays (17-19 vs. 25-34). Additionally, it can be distinguished from M. margitae by the shape of the first humeral spot (vertically elongate $v s$. horizontally elongate); and from M. moisae by number of lateral line scales (36-37vs. 41-47).

Moenkhausia dasalmas possesses a reticulated color pattern over the body, and a vertically elongate humeral spot. These two characters are color based diagnostic features for the M. oligolepis species complex (Costa, 1994; Lima \& ToledoPiza, 2001; Benine, 2002; Lima et al., 2007; Benine et al., 2009; Sousa et al., 2010) when associated with the presence of a conspicuous and broad caudal peduncle spot preceded by a pale light area (except $M$. diktyota), and frequently, reddish eyes on live specimens. This group consists of $M$. oligolepis Günther, M. sanctaefilomenae Steindachner, M. cotinho Eigenmann, $M$. pyrophthalma Costa, $M$. diktyota, and $M$. forestii Benine, Mariguela \& Oliveira. Moenkhausia dasalmas does not belong to the $M$. oligolepis species complex by the absence of a conspicuous and broad caudal peduncle spot and reddish eyes on live specimens, and also differs from the species of this group by the larger number of perforated scales on the lateral line (36-37vs. at most 34), and longitudinal scale rows above (7-8vs. at most 6) and bellow (6-7 vs. less than 4) the lateral line.

The dorsal fin in the characid species is commonly constituted by unbranched and branched rays, generally the common condition is two unbranched rays followed by nine branched rays (ii,9), or by eight branched rays (ii,8), as found in the integrants of the "clade A" (sensu Malabarba \& Weitzman, 2003). Most characids present two evident anteriormost unbranched rays, but sometimes a tiny and barely developed ray can be present just anterior to these ones, which can be seen externally or under the skin on cleared and stained specimens. Moenkhausia dasalmas however, present one tiny unbranched ray under the skin, followed by three larger posteriorly increasing in length unbranched rays in the dorsal fin. A similar pattern, constituted by the presence of three developed unbranched rays in the dorsal fin, is also found in in Astyanax hermosus Miquelarena, Protogino \& López (iii,8-10), H. notidanos Carvalho \& Bertaco (iii,8 or ii,9), Hyphessobrycon fernandezi Fernández-Yépez (iii,8), $H$. oritoensis García-Alzate, Román-Valencia \& Taphorn (iii,8), H. paucilepsis García-Alzate et al. (iii,8), and H. ocasoensis García-Alzate \& Román-Valencia (iii,8). The tiny ray that precedes the unbranched rays in $M$. dasalmas presents the same shape and position as the tiny ray of the other characids with two exposed unbranched rays. However, its evolutionary history still needs deeper investigation.

Moenkhausia dasalmas inhabits headwater environments and has reduced number of branched anal-fin rays and lower body depth, two of the main characters of the Astyanax scabripinnis species complex (Bertaco \& Lucena, 2006). It

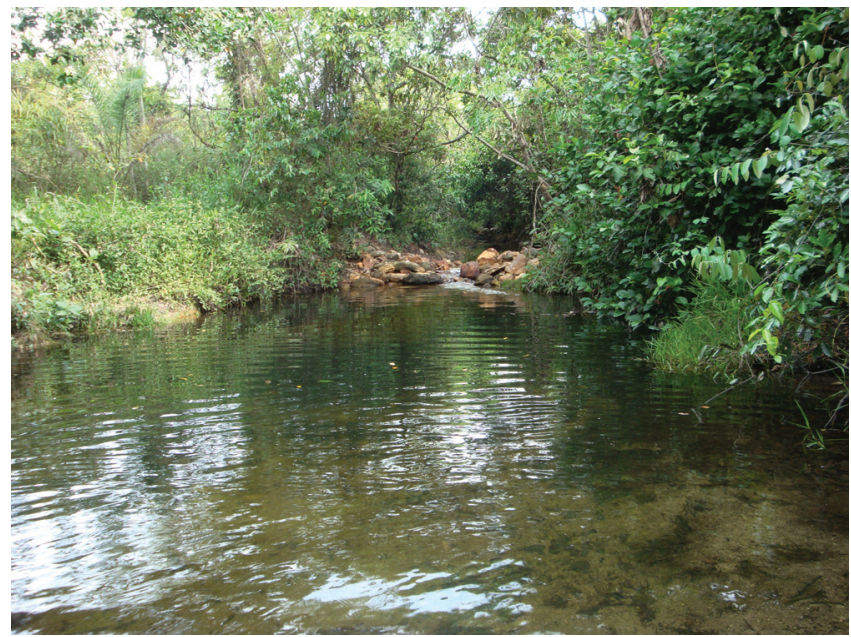

Fig. 6. Type locality of Moenkhausia dasalmas, tributary of rio das Almas, Cavalcante, Goiás, Brazil. 
can be distinguished from the species of the genus Astyanax and from this species complex by the number of dorsal-fin rays (iii, $9 v s$. ii,9), presence of scales on base of upper and along first third of lower caudal-fin lobes, and middle caudalfin rays unpigmented.

Five Moenkhausia species have previously been described from the rio Tocantins-Araguaia basin: M. loweae Géry and $M$. pyrophthalma Costa from the rio Araguaia drainage; $M$. hysterosticta, $M$. pankilopteryx, and $M$. tergimacula Lucena \& Lucena from the rio Tocantins drainage. Moenkhausia dasalmas differs from the aforementioned species by the number of branched anal-fin rays (17-19vs. 24-30, except $M$. pyrophthalma), by the number of humeral spot ( $2 v s .1$, except M. pankilopteryx), and from M. pyrophthalma by the number of lateral line scales (36-37 vs. 27-28).

The region of the type locality of Moenkhausia dasalmas, Chapada dos Veadeiros, in the Brazilian Cerrado, holds undoubtedly enormous biologic diversity (Bertaco et al., 2010). For freshwaters fishes, besides the 35 species mentioned in Bertaco \& Carvalho (2010), adds up now Astyanax courensis Bertaco, Carvalho \& Jerep, Hasemania kalunga Bertaco \& Carvalho, Hemigrammus tocantinsi, Moenkhausia dasalmas described here (Characidae), Hypoptopoma muzuspi Aquino \& Schaefer (Loricariidae), Sternarchorhynchus mesensis Campos-da-Paz (Apteronotidae), and Rivulus tocantinensis Costa (Rivulidae). This corroborates this area as holder of high biodiversity to neotropical freshwater fishes.

Comparative material. In addition to the comparative material listed in Bertaco \& Lucinda (2006), the following specimens were analyzed: Brazil: Moenkhausia cosmops, MZUSP 93494, holotype, $42.4 \mathrm{~mm}$ SL, Mato Grosso, córrego Vinte e Cinco de Maio, near its mouth at the rio Papagaio. Moenkhausia diamantina, MNRJ 21995 , 2 of 17 paratypes, 57.2-58.3 mm SL, Bahia, Lençóis, foz do rio Toalhas, rio Paraguaçu basin. Moenkhausia diktyota, MZUSP 62614, holotype, $52.3 \mathrm{~mm} \mathrm{SL}$; INPA 16200, paratype, $49.6 \mathrm{~mm} \mathrm{SL}$, Amazonas, Santa Isabel do Rio Negro, rio Negro, igarapé at São João, near Santa Isabel do Rio Negro. Moenkhausia heikoi, MZUSP 83536, holotype, $46.5 \mathrm{~mm}$ SL, Pará, rio Iriri, a left-hand tributary of the rio Xingu well above Altamira, about $10 \mathrm{~km}$ below mouth of River Novo. Moenkhausia hemigrammoides, MZUSP 30531, 2 of 1586, 30.3-31.6 mm SL, Roraima, Rio Branco, cachoeira do Bem Querer. Moenkhausia latissimus, USNM 120277, 3 syntypes, 50.7$66.7 \mathrm{~mm}$ SL, Amazonas, Tabatinga. Moenkhausia pyrophtalma, MZUSP 45290, 1 of 7 paratypes, $30.4 \mathrm{~mm} \mathrm{SL}$, stream crossing road between Água Boa and Cocalinho, rio Araguaia-Tocantins basin. Colombia: Moenkhausia eigenmanni, USNM 198640, holotype, $49.3 \mathrm{~mm} \mathrm{SL}$, río Manacacias into upper río Meta, at Restrepo, $c a$. 200 miles E of Bogotá. Ecuador: Moenkhausia naponis, USNM 164067, holotype, 53.0 mm SL, Napo-Pastaza, río Arajuno, upper Napo, few kilometers NE of El Puyoand; ANSP 75901, 3 paratypes, 53.9-58.4 mm SL, Napo-Pastaza, río Oglan, from headwaters, río Napo system. French Guiana: Moenkhausia georgiae, ANSP 139714, 2 paratypes, 37.1-48.9 mm SL, between 'Saut-Chien' and 'Saut-Topi-Topi', middle Mana River. Venezuela: Moenkhausia pittieri, CAS 62059, holotype, $44.1 \mathrm{~mm} \mathrm{SL}$, and CAS 62060, 10 of 27 paratypes, $32.6-41.5 \mathrm{~mm} \mathrm{SL}$, Concejo, rio Tiquirito.

\section{Acknowledgements}

We are indebted to Guilherme Frainer (UFRGS) for his help at field work; Andréia Turcati (UFRGS) for helping with the analysis of stomach contents; Juliano Ferrer (UFRGS) by the identification of Ituglanis specimens. For museum and technical support and/or loan of material we thanks Carlos Lucena (MCP), Lucia Py-Daniel, Marcelo Rocha (INPA), Osvaldo Oyakawa, Flávio Lima (MZUSP), Paulo Buckup, Marcelo Britto (MNRJ), Richard Vari, Sandra Raredon, Jeff Clayton, Jeff Willians (NMNH), John Lundberg, Mark SabajPérez (ANSP), David Catania, and Jon Fong (CAS). VAB is financed by a postdoctoral fellowship from CNPq (Proc. 150042/2009-4). FCJ and FRC are supported by a doctoral fellowship from CAPES and CNPq (Procs. 141028/2007-6 and 201513/2009-9), respectively. Field work support was in part provided by CNPq (Proc. 479412/2008-1). Collecting permits were provided by Instituto Brasileiro do Meio Ambiente e dos Recursos Naturais Renováveis - IBAMA (\# 1507-1).

\section{Literature Cited}

Benine, R. C. 2002. Moenkhausia levidorsa, a new species from rio Aripuanã, Amazon basin, Brazil (Characiformes: Characidae). Ichthyological Exploration of Freshwaters, 13(4): 289-294.

Benine, R. C., T. C. Mariguela \& C. Oliveira. 2009. New species of Moenkhausia Eigenmann, 1903 (Characiformes: Characidae) with comments on the Moenkhausia oligolepis species complex. Neotropical Ichthyology, 7(2): 161-168.

Bertaco, V. A. \& C. A. S. Lucena. 2006. Two new species of Astyanax (Ostariophysi: Characiformes: Characidae) from eastern Brazil with a synopsis of the Astyanax scabripinnis species complex. Neotropical Ichthyology, 4(1): 53-60.

Bertaco, V. A. \& P. H. F. Lucinda. 2006. Moenkhausia pankilopteryx, new species from rio Tocantins drainage, Brazil (Ostariophysi: Characiformes, Characidae). Zootaxa, 1120: 57-68.

Bertaco, V. A. \& F. R. Carvalho. 2010. New species of Hasemania (Ostariophysi: Characiformes: Characidae) from Central Brazil, with comments on the endemism of upper rio Tocantins basin, Goiás State. Neotropical Ichthyology, 8(1): 27-32.

Bertaco, V. A., F. R. Carvalho \& F. C. Jerep. 2010. Astyanax goyanensis (Miranda-Ribeiro, 1944), new combination and Astyanax courensis, new species (Ostariophysi: Characiformes): two Characidae from the upper rio Tocantins basin, Central Brazil. Neotropical Ichthyology, 8(2): 265-275.

Burns, J. R. \& S. H. Weitzman. 1996. Novel gill-derived gland in the male swordtail characin, Corynopoma riisei (Teleostei: Characidae: Glandulocaudinae). Copeia, 1996(3): 627-633.

Carvalho, T. P. \& V. A. Bertaco. 2006. Two new species of Hyphessobrycon (Teleostei: Characidae) from upper rio Tapajós basin on Chapada dos Parecis, Central Brazil. Neotropical Ichthyology, 4(3): 301-308.

Carvalho, F. R., V. A. Bertaco \& F. C. Jerep. 2010. Hemigrammus tocantinsi: a new species from the upper rio Tocantins basin, Central Brazil (Characiformes: Characidae). Neotropical Ichthyology, 8(2): 247-254.

Costa, W. J. E. M. 1994. Description of two new species of the genus Moenkhausia (Characiformes, Characidae) from central Brazil. Zoologischer Anzeiger, 232 (1/2): 21-29. 
Eigenmann, C. H. 1917. The American Characidae [Part 1]. Memoirs of the Museum of Comparative Zoology 43(1): 1-102.

Eigenmann, C. H. 1918. The American Characidae [Part 2]. Memoirs of the Museum of Comparative Zoology 43(1): 103-208.

Eschmeyer, W. N. \& R. Fricke. 2010. Catalog of Fishes. Electronic version - July 12, 2010. California Academy of Sciences. Avalaible at: http://research.calacademy.org/ichthyology/catalog/ fishcatmain.asp. Accessed July 15, 2010.

Fink, W. L. \& S. H. Weitzman. 1974. The so-called cheirodontin fishes of Central America with descriptions of two new species (Pisces: Characidae). Smithsonian Contributions to Zoology, 172: 1-46.

García-Alzate, C. A. \& C. Román-Valencia. 2008. Hyphessobrycon ocasoensis sp. n. (Teleostei, Characidae) una nueva especie para el Alto Cauca, Colombia. Animal Biodiversity and Conservation, 31(2): 11-23.

García-Alzate, C. A., C. Román-Valencia \& D. C. Taphorn. 2008. Revision of the Hyphessobrycon heterorhabdus-group (Teleostei: Characiformes: Characidae), with description of two new species from Venezuela. Vertebrate Zoology, 58(2): 139-157.

Géry, J. 1977. Characoids of the World. T. F. H. Publications, Neptune City, NJ, 672p.

Lima, F. C. T., L. R. Malabarba, P. A. Buckup, J. F. Pezzi da Silva, R. P. Vari, A. Harold, R. Benine, O. T. Oyakawa, C. S. Pavanelli, N. A. Menezes, C. A. S. Lucena, M. C. S. L. Malabarba, Z. M. S. Lucena, R. E. Reis, F. Langeani, L. Casatti, V. A. Bertaco, C. Moreira \& P. H. F. Lucinda. 2003. Genera incertae sedis in Characidae. Pp. 106-169. In: Reis, R. E., S. O. Kullander \& C. J. Ferraris (Eds.). Check List of the Freshwater Fishes of South and Central America. Porto Alegre, Edipucrs, 729p.

Lima, F. C. T. \& M. Toledo-Piza. 2001. New species of Moenkhausia (Characiformes: Characidae) from the rio Negro of Brazil. Copeia, 2001(4): 1058-1063.
Lima, F. C. T., H. A. Britski \& F. A. Machado. 2007. A new Moenkhausia (Characiformes: Characidae) from central Brazil, with comments on the area relationship between the upper rio Tapajós and upper rio Paraguai systems. Aqua, International Journal of Ichthyology, 13(2): 45-54.

Lucinda, P. H. F., L. R. Malabarba \& R. C. Benine. 2007. On a new species of the genus Moenkhausia Eigenmann (Ostariophysi: Characidae). Zootaxa, 1525: 61-68.

Malabarba, L. R. \& S. H. Weitzman. 2003. Description of new genus with six new species from southern Brazil, Uruguay and Argentina, with a discussion of a putative characid clade (Teleostei: Characiformes: Characidae). Comunicações do Museu de Ciências e Tecnologia da PUCRS, Série Zoologia, 16(1): 67-151.

Marinho, M. F. 2010. A new species of Moenkhausia Eigenmann (Characiformes: Characidae) from the rio Xingu basin, Brazil. Neotropical Ichthyology, 8(3): 655-659.

Miquelarena, A. M., L. C. Protogino \& H. L. López. 2005. Astyanax hermosus, a new species from the Primero River basin, Córdoba, Argentina (Characiformes, Characidae). Revue suisse de Zoologie, 112(1): 13-20.

Mirande, J. M. 2010. Phylogeny of the family Characidae (Teleostei: Characiformes): from characters to taxonomy. Neotropical Ichthyology, 8(3): 385-568.

Sousa, L. M., A. L. Netto-Ferreira \& J. L. Birindelli. 2010. Two new species of Moenkhausia Eigenmann (Characiformes: Characidae) from Serra do Cachimbo, Pará, Northern Brazil. Neotropical Ichthyology, 8(2): 255-264.

Taylor, W. R. \& G. C. van Dyke. 1985. Revised procedures for staining and clearing small fishes and other vertebrates for bone and cartilage study. Cybium, 9(2): 107-119. 